\title{
Radiosensitization effects by bismuth oxide nanorods of different sizes in megavoltage external beam radiotherapy
}

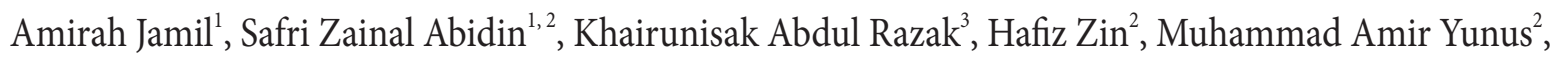 \\ Wan Nordiana Rahman ${ }^{1}$
}

\begin{abstract}
${ }^{1}$ School of Health Sciences, Health Campus, Universiti Sains Malaysia, Kubang Kerian, Kota Bharu, Kelantan, Malaysia
${ }^{2}$ Advanced Medical and Dental Institute, Universiti Sains Malaysia, Bertam, Kepala Batas, Penang Malaysia

${ }^{3}$ School of Materials and Mineral Resources Engineering, Universiti Sains Malaysia, Nibong Tebal, Penang, Malaysia
\end{abstract}

\begin{abstract}
Background: Nanotechnology application has successfully reached numerous scientific breakthroughs including in radiotherapy. However, the clinical application of nanoparticles requires more diligent research primarily on the crucial parameters such as nanoparticle sizes. This study is aimed to investigate the influence of bismuth oxide nanorod $\left(\mathrm{Bi}_{2} \mathrm{O}_{3}-\mathrm{NR}\right)$ sizes on radiosensitization effects on MCF-7 and HeLa cell lines for megavoltage photon and electron beam radiotherapy.

Materials and methods: MCF- 7 and HeLa cells were treated with and without $0.5 \mu \mathrm{Mol} / \mathrm{L}$ of $\mathrm{Bi}_{2} \mathrm{O}_{3}$-NR of varying sizes $(60,70$, 80 , and $90 \mathrm{~nm}$ ). The samples, including the control groups, were exposed to different radiation doses (0-10 Gy), using photon ( $6 \mathrm{MV}$ and $10 \mathrm{MV}$ ), and electron beam ( $6 \mathrm{MeV}$ and $12 \mathrm{MeV}$ ) radiotherapy. Clonogenic assay was performed, and sensitization enhancement ratio (SER) was determined from linear quadratic based cell survival curves.

Results: The results depicted that $60 \mathrm{~nm} \mathrm{Bi}{ }_{2} \mathrm{O}_{3}$-NR yields the most excellent SER followed by $70 \mathrm{~nm} \mathrm{Bi} \mathrm{O}_{3}$-NR. Meanwhile, the 80 and $90 \mathrm{~nm} \mathrm{Bi}{ }_{2} \mathrm{O}_{3}$-NR showed an insignificant difference between treated and untreated cell groups. This study also found that MCF-7 was subjected to more cell death compared to HeLa.

Conclusion: $60 \mathrm{~nm} \mathrm{Bi}{ }_{2} \mathrm{O}_{3}-\mathrm{NR}$ was the optimal $\mathrm{Bi}_{2} \mathrm{O}_{3}-\mathrm{NR}$ size to induce radiosensitization effects for megavoltage external beam radiotherapy. The SER in photon beam radiotherapy marked the highest compared to electron beam radiotherapy due to decreased primary radiation energy from multiple radiation interaction and higher Compton scattering.
\end{abstract}

Key words: bismuth oxide nanorods; cancer cell lines; electron beam; nanoparticles; photon beam; radiosensitization Rep Pract Oncol Radiother 2021;26(5):773-784

\section{Introduction}

Nanotechnology has unveiled breakthroughs in the medical field, especially in radiotherapy (RT) through diagnostic as well as therapeutic application, leading to improved treatment efficacy [1-4]. RT treatment comprises the delivery of high-intensity radiation dose in situ to initiate cancer cell death. Unfortunately, treatment by RT not only induces DNA damage to the malignant tumour cells but simultaneously prompts destruction of the neighboring normal tissues [5-7]. The survived destructed cells might be able to recover or be incapable of repairing themselves properly, causing DNA mutation and secondary cancers. Radioresistant cancer cells also impose a high risk to healthy tissue where the treatment might require elevated radiation dose that will jeopardize

Address for correspondence: Wan Nordiana Rahman, Medical Radiation Programme, School of Health Sciences, Health Campus, Universiti Sains Malaysia, 16150 Kubang Kerian, Kota Bharu, Kelantan, Malaysia, tel: (+60) 97677811; e-mail: wandiana@usm.my 
the normal cells. Therefore, increasing the efficiency of RT has been one of the top priorities in the oncology field not only to achieve more significant tumour cell killing but also to salvage the normal cells surrounding it [8]. In this intricate challenge, it is reported that the use of nanoparticles (NPs) as radiosensitizers aid in increasing the efficacy of $\mathrm{RT}$, reducing radiation dose to the normal cells, and reduce the development of radioresistant cancer cells [8-24]. The NP is the agent lower than $100 \mathrm{~nm}$ in size that allows radiation to be targeted at the tumor site and absorbed, resulting in radiosensitization [20]. In radiotherapy, metal NPs have been reported in several studies to have a high radiosensitization ratio (SER), due to their high atomic $(Z)$ number [21-24]. This occurrence is explained by the boosted DNA damage induced by the photoelectric and Compton scattering effect via the metal NPs. Despite the discovery of the therapeutic function of metal NPs, the radiosensitization effectiveness is dependent on different factors such as the NP shape, surface properties, size, concentration, radiation energy delivered, spectral composition, intracellular uptake efficiency, intracellular transport properties, adsorption of protein molecules on the NPs and not limited to NPs administration route [23-24]. Consequently, it is crucial to conduct more evidence-based experimental studies on the factors affecting radiosensitization effects.

Owing to its higher atomic number ( $\mathrm{Z})$, good energy absorption, and low toxicity, bismuth has a higher potential in comparison to gold and platinum nanoparticles for cancer treatment. Careful bismuth synthesis is required so that its morphology, size and pharmacokinetics will not have negative side effects, especially for in vivo application. Through many synthesis methods, various sizes of bismuth nanoparticles ranging from 0.5 to $200 \mathrm{~nm}$ have been produced [25, 26]. Beside the size, bismuth nanoparticles can also be synthesized in many shapes such as sphere, nanowire, nanobelt, needle, and nanocube [27-29]. The variety of nanoparticle morphologies gives bigger opportunity for this material to be applied in various fields. Methods of bismuth nanoparticle synthesis include slow oxidation, precipitation, atomic-pressure chemical vapor deposition (CVD), metal-organic deposition, oxidative metal vapor-phase deposition, and dispersion [30, 31].
All of these methods require the use of complex tools, high temperature, and longer reaction time. Therefore, hydrothermal method was used in this study because of cost effectiveness and simple protocol. Hydrothermal method is one of the methods to produce different chemical compounds and materials using high temperature and pressure for a long time. Material synthesis via the hydrothermal method involved the crystallization process directly from solution that occurs in two stages which is the crystal nucleation and subsequent controls growth $[32,33]$. Following the crystal nucleation and control growth is the morphological formation of the hydrothermal products where the particle size, morphology and the degree of crystallinity can be controlled by simply changing the experimental parameters. Hence, this study is focused on investigating the optimal size of bismuth nanorods $\left(\mathrm{Bi}_{2} \mathrm{O}_{3}\right.$-NR) to induce significant radiosensitization effect on $\mathrm{MCF}-7$ and HeLa cells for megavoltage photon and electron beam radiotherapy.

\section{Materials and methods}

\section{Cell culture protocol}

MCF-7 (breast carcinoma) and HeLa (cervical carcinoma) cell lines were obtained from American Type Culture Collection (ATCC, USA), maintained in completed Dulbecco's Modified Eagle Medium (DMEM, Life Technologies, USA). The completed media was supplemented with $10 \%$ fetal bovine serum (FBS, Life Technologies, USA) and $1 \%$ penicillin-streptomycin (Life Technologies, USA). The cells cultured was incubated at $37^{\circ} \mathrm{C}$ in humidified condition with $5 \%$ carbon dioxide $\left(\mathrm{CO}_{2}\right)$.

Cell passaging routine was performed when the cells reached at least $70 \%$ confluency to increase the proliferation rate and to provide new media to the newly divided cell in culture flasks. Excess debris and dead cells were washed twice using $2 \mathrm{~mL}$ phosphate buffer saline (PBS, Life Technologies, USA) before $1 \mathrm{~mL}$ cell detaching reagent, TrypLE (Life Technologies, USA) was applied to the cells and left incubated for $2 \mathrm{~min}$ utes. $2 \mathrm{~mL}$ of complete DMEM was used to neutralize the TrypLE enzyme, and the cells were transferred into the $15 \mathrm{~mL}$ falcon tube (Falcon, Fisher Scientific, USA) for centrifugation of 1500 rpm for 5 minutes. 


\section{Synthesis of $\mathrm{Bi}_{2} \mathrm{O}_{3}-\mathrm{NR}$}

$\mathrm{Bi}_{2} \mathrm{O}_{3}$-NR was synthesized using a hydrothermal method. Glassware was washed using aqua regia solution of $\left(\mathrm{HCl}: \mathrm{HNO}_{3}, 3: 1, \mathrm{v} / \mathrm{v}\right)$. First, varying weights of bismuth (III) nitrate pentahydrate (Sigma Aldrich, U.S.A.) were dissolved in $40 \mathrm{~mL}$ of distilled water. Subsequently, under 45 minutes of continuous stirring, $3 \mathrm{mMol} / \mathrm{L}$ of sodium sulfate (Sigma Aldrich, USA) was added to the solution. Next, $18 \mathrm{mM}$ of sodium hydroxide $(\mathrm{NaOH})$ was added slowly into the solution using a dropper until yellowish precipitates were formed. The yellowish precipitate was then transferred into a Schott bottle and sealed tightly. Then the precipitation was incubated in an oven at $60^{\circ} \mathrm{C}$ for 10 minutes. The samples were then allowed to cool at room temperature. The sample produced was washed with distilled water thrice, followed by $70 \%$ ethanol before being dried in an oven at $80^{\circ} \mathrm{C}$ to obtain the final yellowish-white $\mathrm{Bi}_{2} \mathrm{O}_{3}$-NR powder. The dried samples were labelled and stored at room temperature.

\section{Characterization of $\mathrm{Bi}_{2} \mathrm{O}_{3}-\mathrm{NR}$}

The synthesized $\mathrm{Bi}_{2} \mathrm{O}_{3}$-NR sample was characterized physically to confirm size, morphology, chemical element details and bonding between bismuth and oxygen of the nanoparticles sample.

\section{Phase identification}

The $1.0 \mathrm{~g}$ of synthesized $\mathrm{Bi}_{2} \mathrm{O}_{3}$ - $\mathrm{NR}$ was weighed for phase identification and crystalline material using X-ray diffractometer (XRD, Bruker AXS D8, USA). On zero-reflective fused silica, a thin layer of vacuum grease was applied before loading the $\mathrm{Bi}_{2} \mathrm{O}_{3}-\mathrm{NR}$ sample. Excess powder was removed by turning the fused silica upside down to get a thin layer of powder before being loaded into the system. The XRD machine operated at a voltage of $30 \mathrm{kV}$ and current $30 \mathrm{~mA}$ with $\mathrm{Cu}-\mathrm{Ka}$ as a radiation source to analyze the sample in $\theta$ to $2 \theta$. The scattering angle was set up in the range of $10^{\circ}$ to $90^{\circ}$ to concentrate the X-ray interaction with $\mathrm{Bi}_{2} \mathrm{O}_{3}$-NR sample and produce a specific wavelength that were detected, processed and counted by Expert software. The software generated the diffraction peaks of the sample that has a unique characteristic in comparison to standard reference patterns.

\section{Morphology and elemental analysis}

To analyze the morphology of the nanoparticles, Field-Emission Scanning Electron Microscope (FESEM, Zeiss Supra 35VP) was used. This FESEM produces images of a sample by scanning the sample with a focused electron beam. Preparation of the sample was conducted by sprinkling $10 \mu \mathrm{g}$ of $\mathrm{Bi}_{2} \mathrm{O}_{3}$-NR powder onto sample stage of FESEM. The $\mathrm{Bi}_{2} \mathrm{O}_{3}$-NR was first dissolved in ethanol and subjected to ultrasonicator for 10 minutes. Then, the dissolved solution was dropped onto a carbon coated 200 mesh copper 62 grid and left for 3 minutes. Any excess suspension was removed by air gun to prevent the sample from agglomerate and gently placed a filter paper on the copper grid. The sample was inserted into the sample chamber and the FESEM was operated at $5 \mathrm{kV}$ to get topography of nanomaterial under various magnifications. The FESEM that generates electron source from field emission will produce a high resolution image. Then the image was analyzed using ImageJ software by counting approximately 100 nanoparticles to determine the average size of $\mathrm{Bi}_{2} \mathrm{O}_{3}-\mathrm{NR}$.

\section{Element composition}

To analyze the chemical element composition of materials, the Energy Dispersive X-Ray analysis (EDX) was used. The EDX that is mounted to Scanning Electron Microscope (SEM) generates x-ray source to produce a spectrum and image. First, the sample of $\mathrm{Bi}_{2} \mathrm{O}_{3}-\mathrm{NR}$ was cleaned using an ultrasonic cleaner and then coated with a carbon coater. Then the sample was mounted onto a specimen holder and inserted into the FESEM chamber to capture the image. The focus zooming was adjusted accordingly to produce a sharp image. Further analysis using liquid nitrogen was conducted by opening the valve and $8 \mu \mathrm{A}$ gun box power to start EDX analysis. The data generated by EDX analysis consist of spectra showing peaks corresponding to the elements making up the true composition of the analyzed sample.

\section{Bismuth-oxygen bonding}

The bonding of $\mathrm{Bi}_{2} \mathrm{O}_{3}$-NR element was carried out using fourier-transform infrared spectroscopy (FTIR, Spectrum One, Perkin Elmer, USA). The $\mathrm{Bi}_{2} \mathrm{O}_{3}$-NR was mixed by ratio of $1: 10$ with potassium bromide $(\mathrm{KBr})$. Then the sample was inserted 
into a mold and compacted with 1 PSA pressure to produce transparent pallet. The machine was operated at a wavelength of $4000 \mathrm{~cm}^{-1}$ to $400 \mathrm{~cm}^{-1}$ with 4 times resolution configuration. Further result analysis was performed to determine the chemical structure of the $\mathrm{Bi}_{2} \mathrm{O}_{3}$-NR by the Spectrum software.

\section{Nanoparticles and cells preparation}

The NPs were prepared by taking a total of 80 $\mathrm{mg}$ of powdered bismuth oxide nanorods that were added to distilled water to produce $86 \mathrm{mMol} / \mathrm{L}$ of $\mathrm{Bi}_{2} \mathrm{O}_{3}-\mathrm{NR}$ solution. Then, the sample was sonicated using an ultrasonic bath (INPG 0315) for one hour for homogenization of the NP and was kept at $4^{\circ} \mathrm{C}$ temperature. The concentration used for the irradiation experiment was $0.5 \mu \mathrm{Mol} / \mathrm{L}$.

The cell samples were prepared before irradiation with $1 \times 10^{4}$ cells of MCF-7 and HeLa cells were well mixed with $\mathrm{Bi}_{2} \mathrm{O}_{3}$-NR in sterile micro vial tubes $(200 \mu \mathrm{L}$, Eppendorf). For the control groups, MCF-7 and HeLa cells were prepared without the treatment of $\mathrm{Bi}_{2} \mathrm{O}_{3}-\mathrm{NR}$. The samples were prepared for every nanoparticle size $(60,70,80$, and $90 \mathrm{~nm})$ including control, and were exposed using different radiation doses (0-10 Gy).

\section{Megavoltage photon and electron beam irradiation}

The irradiation of the samples with and without $\mathrm{Bi}_{2} \mathrm{O}_{3}$-NR was conducted at Radiotherapy section, Advanced Medical and Dental Institute, Universiti Sains Malaysia. Linear accelerator or LINAC (Elekta Synergy, Sweden) was used to irradiate the samples with different energy of megavoltage photon and electron beam.

Irradiation of samples was made by placing the samples onto a solid water phantom $(10 \mathrm{~cm})$, and then the bolus of $1.5 \mathrm{~cm}$ (depth of maximum dose) was placed on top of the samples for $6 \mathrm{MV}$ photon beam irradiation. Meanwhile, a $2.5 \mathrm{~cm}$ bolus was used for $10 \mathrm{MV}$ photon beam energy to deliver the maximum dose. The source-to-surface distance (SSD) was kept constant at $100 \mathrm{~cm}$. The irradiation field size was collimated to $10 \times 10 \mathrm{~cm}^{2}$. Subsequently, the sample was exposed to various radiation dose, starting from $0.0,0.5,1.0,1.5,2.0,4.0$, 6.0, 8.0, 9.0 and 10.0 Gy. Each radiation dose was done in a single fraction with a dose rate of 599 $\mathrm{MU} / \mathrm{min}$.
The samples for electron beam irradiation were set up according to the photon beam procedure, in which the sample was put on a solid water phantom $(10 \mathrm{~cm})$ and covered with $2.5 \mathrm{~cm}$ bolus to deliver maximum dose for $6 \mathrm{MeV}$ and bolus $3.5 \mathrm{~cm}$ for 12 $\mathrm{MeV}$. The SSD was designated at $100 \mathrm{~cm}$, and the 10 $\mathrm{x} 10 \mathrm{~cm} 2$ electron applicator was used to minimize scattering effects. The samples were irradiated with different radiation dose, starting from $0.0,0.5,1.0$, $1.5,2.0,4.0,6.0,8.0,9.0$ and $10.0 \mathrm{~Gy}$. The dose rate was kept constant at $599 \mathrm{MU} / \mathrm{min}$, and it was also done in a single fraction.

\section{Clonogenic assays}

The irradiated samples were sub-cultured into the 6-well plates, with added $2 \mathrm{ml}$ completed DMEM to disperse the cells. All plates were incubated at $37^{\circ} \mathrm{C}$ with a humidified condition of $5 \%$ $\mathrm{CO}_{2}$ for 5 days. After a 5-day incubation period, culture media were carefully discarded from each well of 6-well plates. Rinsing with PBS was done three times. Next, $2 \mathrm{~mL}$ of ice-cold methanol (Sigma Aldrich, U.S.A.) was added to each well and left to fix in the incubator for 30 minutes. The samples were stained using $2 \mathrm{~mL}$ crystal violet after the fixing agent was removed. The plate was incubated at room temperature for 1 hour. Finally, the plates were immersed in tap water to rinse off crystal violet and were left to dry at room temperature overnight.

\section{Cell survival analysis}

The formation of cell colony after irradiation was counted, and the cell survival curve was plotted using OriginLab 8.5 software (OriginLab Corporation, Northampton, USA) based on the linear-quadratic model as shown in equation 1 .

$$
S(D)=\exp -\alpha D+\beta D^{2}
$$

The survival fraction was generated to fit the experimental data point to the linear model, which automatically determined the value of $\alpha$ and $\beta$. Where the $S(D)$ is the fraction of cells surviving a dose (D), $\alpha$ is a constant describing the linear slope of the cell survival curve, and $\beta$ is a quadratic component of cell killing. Then, SER can be determined through this graph to indicate the radiosensitizing effects of $\mathrm{Bi}_{2} \mathrm{O}_{3}$-NR to MCF-7 and HeLa cell lines. In this study, the survival fraction was set to 
$50 \%$ to get the radiation dose for control and treatment. The SER value for each size and concentration could be used to measure lethal dose for the loss of proliferative capacity to $50 \%$ in the presence of $\mathrm{Bi}_{2} \mathrm{O}_{3}$-NR using equation 2 .

$$
\text { SER }=\frac{\begin{array}{c}
\text { Dose at } 50 \% \text { cell survival } \\
\text { (without NPs) }
\end{array}}{\begin{array}{c}
\text { Dose at } 50 \% \text { cell survival } \\
\text { (with NPs) }
\end{array}}
$$

\section{Results}

\section{Characterization of $\mathrm{Bi}_{2} \mathrm{O}_{3}-\mathrm{NR}$}

The XRD was carried out to determine the crystalline phase of the nanoparticle's powders. Figure 1 shows the XRD diffraction pattern of $\mathrm{Bi}_{2} \mathrm{O}_{3}$ for different concentration of the $\mathrm{Bi}\left(\mathrm{NO}_{3}\right)_{3} \cdot 5 \mathrm{H}_{2} \mathrm{O}$ samples. The XRD pattern shows the samples synthesized are in crystalline state which matched the $\mathrm{Bi}_{2} \mathrm{O}_{3}$-NR reference. However, sample synthesized with 0.05 and $0.1 \mathrm{Mol} / \mathrm{L}$ of $\mathrm{Bi}\left(\mathrm{NO}_{3}\right)_{3} \cdot 5 \mathrm{H}_{2} \mathrm{O}$ exhibit typical strong and sharp peaks, while samples prepared with 0.2 and $0.3 \mathrm{Mol} / \mathrm{L}$ of $\mathrm{Bi}\left(\mathrm{NO}_{3}\right)_{3} \cdot 5 \mathrm{H}_{2} \mathrm{O}$ had smaller and broad peaks.

This indicates the concentration of $\mathrm{Bi}\left(\mathrm{NO}_{3}\right)_{3} \cdot 5 \mathrm{H}_{2} \mathrm{O}$ directly affect the size of nanoparticles that will be produced. All of the reflections of the XRD patterns also show that no peaks of any other phases were detected, which indicates the high purity of synthesized $\mathrm{Bi}_{2} \mathrm{O}_{3}$ particles. These reveals that $\mathrm{Bi}_{2} \mathrm{O}_{3}$ particles can be produced by this method with low temperature, short time and simple sealed container.

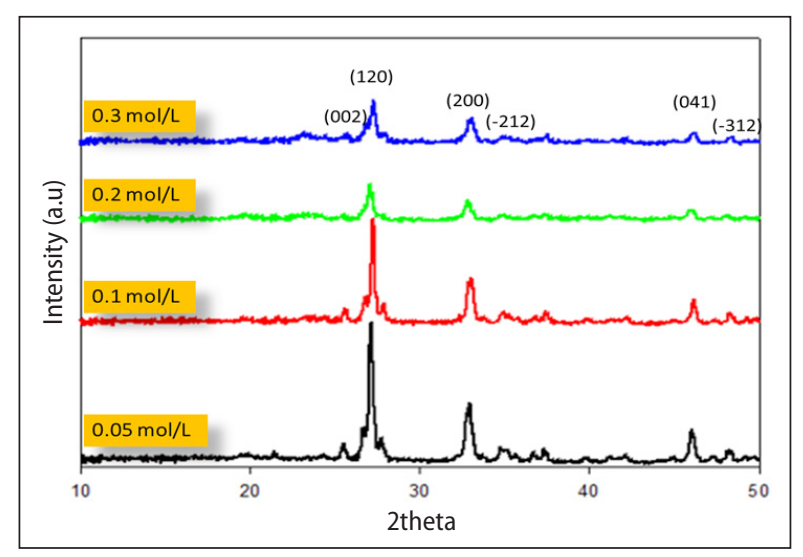

Figure 1. XRD patterns of $\mathrm{Bi}_{2} \mathrm{O}_{3}-\mathrm{NR}$ synthesized using the hydrothermal method with varying $\mathrm{Bi}\left(\mathrm{NO}_{3}\right)_{3} \cdot 5 \mathrm{H}_{2} \mathrm{O}$ concentration, $0.05,0.1,0.2$ and $0.3 \mathrm{Mol} / \mathrm{L}$
As previously mentioned, the hydrothermal method involved the crystallization process directly from solution that occurs in two stages which is the crystal nucleation and subsequent controls growth [32]. During the hydrothermal reaction at $60^{\circ} \mathrm{C}$ for 10 min, the amount of $\mathrm{Bi}\left(\mathrm{NO}_{3}\right)_{3}$ concentration that was mixed with $\mathrm{Na}_{2} \mathrm{SO}_{4}$ and $\mathrm{NaOH}$ directly affected the number of nuclei, which determined the nucleation and growth process. Since the number of nuclei increased with increasing $\mathrm{Bi}\left(\mathrm{NO}_{3}\right)_{3} \cdot 5 \mathrm{H}_{2} \mathrm{O}$, less ions could diffuse per nuclei. Thus, particle size will decrease and produce small size nanoparticles.

Hydrothermal process is usually carried out in a sealed container such as Teflon coated autoclave or sealed container. The reaction which takes place in an aqueous solution occurs at a temperature higher than room temperature, and at a pressure higher than $100 \mathrm{kPa}$. Under this condition, crystals started to grow in the form of powder or film [34]. Interaction between bismuth reactant and surfactant template stabilizes the $\mathrm{Bi}_{2} \mathrm{O}_{3}$ framework, thus preventing it from collapsing caused by pressure and internal stress during the drying process. Several works on the synthesis of $\mathrm{Bi}_{2} \mathrm{O}_{3}$ nanoparticles using the hydrothermal method with different parameters such as temperature, time, starting material concentration, and amount of surfactant have been reported [28, 35-36].

In an instance of $\mathrm{Bi}_{2} \mathrm{O}_{3}$ needles synthesis, they were hydrothermally fabricated by adjusting the starting materials, mineralizers, reaction temperature and time [37]. At a low temperature of $120^{\circ} \mathrm{C}$ in 0.5 hours, $\mathrm{Bi}_{2} \mathrm{O}_{3}$ needles of a monoclinic structure could be fabricated rapidly. It was shown that the diameter of the $\mathrm{Bi}_{2} \mathrm{O}_{3}$ needles increased with the increasing reaction temperature and time.

\section{Morphology and elemental analysis}

The morphologies of samples were investigated by TEM that produces images to analyze size and shape of particles. Figure 2 shows typical FESEM images of $\mathrm{Bi}_{2} \mathrm{O}_{3}$ nanostructures synthesized at $60^{\circ} \mathrm{C}$ for 10 minutes. The samples demonstrate that the synthesized $\mathrm{Bi}_{2} \mathrm{O}_{3}$ has a rod shape with several nanometers in size. The $\mathrm{Bi}_{2} \mathrm{O}_{3}-\mathrm{NR}$ are relatively crystallite in a single crystal without agglomeration. Then the size of dispersed nanorods was measured using ImageJ software and the uniform sizes from 60, 70, 80 and $90 \mathrm{~nm}$ were obtained with $\mathrm{Bi}\left(\mathrm{NO}_{3}\right)_{3} \cdot 5 \mathrm{H}_{2} \mathrm{O}$ concentration of $0.3,0.2,0.1$ and 

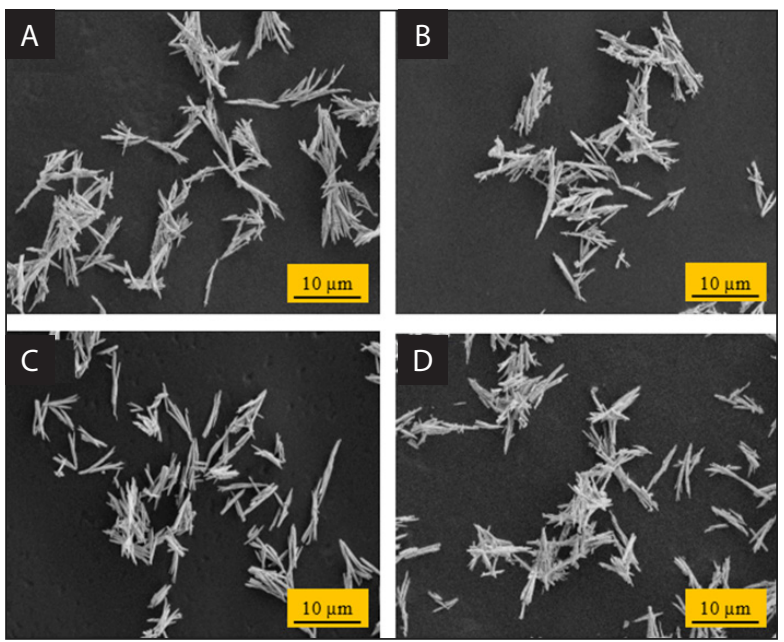

Figure 2. FESEM images of $\mathrm{Bi}_{2} \mathrm{O}_{3}-\mathrm{NR}$ obtained at $60^{\circ} \mathrm{C}$ for 10 minutes with varying $\mathrm{Bi}\left(\mathrm{NO}_{3}\right)_{3} \cdot 5 \mathrm{H}_{2} \mathrm{O}$ concentration. The $\mathrm{Bi}\left(\mathrm{NO}_{3}\right)_{3} \cdot 5 \mathrm{H}_{2} \mathrm{O}$ with $(\mathbf{A}) 0.05 \mathrm{Mol} / \mathrm{L}$ produced $90 \mathrm{~nm}$, (B) 0.1 $\mathrm{Mol} / \mathrm{L}$ produced $80 \mathrm{~nm},($ C) $0.2 \mathrm{Mol} / \mathrm{L}$ produced $70 \mathrm{~nm}$, and (D) $0.3 \mathrm{Mol} / \mathrm{L}$ produced $60 \mathrm{~nm}$ of $\mathrm{Bi}_{2} \mathrm{O}_{3}-\mathrm{NR}$

$0.05 \mathrm{Mol} / \mathrm{L}$, respectively. Table 1 summarized the effect of $\mathrm{Bi}\left(\mathrm{NO}_{3}\right)_{3} \cdot 5 \mathrm{H}_{2} \mathrm{O}$ concentration in producing different sizes of $\mathrm{Bi}_{2} \mathrm{O}_{3}$-NR.

In the hydrothermal technique, the formation process of bismuth oxide nanorods is proposed from dissolution-crystallization, where the basic dissolution mechanism of $\mathrm{Bi}\left(\mathrm{NO}_{3}\right)_{3} \cdot 5 \mathrm{H}_{2} \mathrm{O}$ and other reactants like $\mathrm{Na}_{2} \mathrm{SO}_{4}$ and $\mathrm{NaOH}$ strongly depend on each other while crystallization only occurs in the supersaturated fluid [38]. At the beginning, $\mathrm{Na}_{2} \mathrm{SO}_{4}$ reduced $\mathrm{Bi}\left(\mathrm{NO}_{3}\right)_{3} \cdot 5 \mathrm{H}_{2} \mathrm{O}$ to $\mathrm{Bi}_{2} \mathrm{O}(\mathrm{OH})_{2} \mathrm{SO}_{4}$ in the solution and formed nanorods at room temperature. This formation is a template in the following step of the reaction. Then by dropping $\mathrm{NaOH}$ solution into the reaction system, $\mathrm{OH}$ - interacts with $\mathrm{Bi}_{2} \mathrm{O}(\mathrm{OH})_{2} \mathrm{SO}_{4}$ leading to the formation of $\mathrm{Bi}(\mathrm{OH})_{3}$. The $\mathrm{Bi}(\mathrm{OH})_{3}$ finally subjected to hydrothermal treatment at $60^{\circ} \mathrm{C}$, will be dehydrated and converted into $\mathrm{Bi}_{2} \mathrm{O}_{3}-\mathrm{NR}$. This principle is similar to the synthesis process of $\mathrm{ZnO}$ nanowires [39-40].

The purpose for adopting $\mathrm{Na}_{2} \mathrm{SO}_{4}$ in $\mathrm{Bi}_{2} \mathrm{O}_{3}-\mathrm{NR}$ synthesis was to produce nano-size particle or structure. Study by Wu et. al. (2011), found that $\mathrm{Na}_{2} \mathrm{SO}_{4}$ plays an important role in reducing the particle size and without adding $\mathrm{Na}_{2} \mathrm{SO}_{4}$, the $\mathrm{Bi}_{2} \mathrm{O}_{3}$ could only be produced as micro rods [36]. The dissolution is another important factor in the hydrothermal method, as it produces more stable phases in precipitating once the supersaturation for the phases is achieved. The formation mechanism sug-
Table 1. Crystallite and particle size (diameter) of $\mathrm{Bi}_{2} \mathrm{O}_{3}-\mathrm{NR}$ with varying $\mathrm{Bi}\left(\mathrm{NO}_{3}\right)_{3} \cdot 5 \mathrm{H}_{2} \mathrm{O}$ concentration

\begin{tabular}{|l|c|}
\hline $\begin{array}{l}\mathrm{Bi}\left(\mathrm{NO}_{3}\right)_{3} \cdot 5 \mathrm{H}_{2} \mathrm{O} \\
\text { concentration }[\mathrm{Mol} / \mathrm{L}]\end{array}$ & $\begin{array}{c}\text { Particle size } \\
{[\mathrm{nm}]}\end{array}$ \\
\hline 0.05 & 90 \\
\hline 0.1 & 80 \\
\hline 0.2 & 70 \\
\hline 0.3 & 60 \\
\hline
\end{tabular}

gests that precipitation processes in homogeneous $\mathrm{Bi}\left(\mathrm{NO}_{3}\right)_{3} \cdot 5 \mathrm{H}_{2} \mathrm{O}$ solutions can be controlled via the hydrothermal method to yield $\mathrm{Bi}_{2} \mathrm{O}_{3}-\mathrm{NR}$.

The formation of nanorod is an important characteristic for the enhancement of radiation therapy effects. Study of metallic nanoparticles showed that the morphology and size of nanoparticles influenced the result of toxicity and degree of radiosensitivity. Metallic nanoparticles smaller than $5 \mathrm{~nm}$ interact directly with DNA after diffusing freely into the cells, resulting in necrosis $[41,42]$. Consequently, these nanoparticles induced toxicity to the cell treatment. Thus, the hydrothermal method is used in this study to synthesize $\mathrm{Bi}_{2} \mathrm{O}_{3}-\mathrm{NR}$ with size $60,70,80$ and 90 $\mathrm{nm}$ (Tab. 1). Beside size, the morphology is the main point that influences the increase of radiotherapy effect which in this study used rods shaped particles.

\section{Element composition}

In order to analyze the elemental aspect of the synthesized sample, energy dispersive X-ray spectroscopy (EDX) was done. Each sample or chemical has a unique atomic number to generate sets of peaks based on its electromagnetic emission spectrum. This unique spectrum-like fingerprint allows the elemental composition of the synthesized sample to be measured by EDX. Figure 3 shows the EDX spectrum obtained from $\mathrm{Bi}_{2} \mathrm{O}_{3}-\mathrm{NR}$ at random spot area. The spectrum reveals that only bismuth and oxygen peaks were observed that indicated the high purity of synthesized $\mathrm{Bi}_{2} \mathrm{O}_{3}-\mathrm{NR}$. This result is consistent with the XRD pattern in Figure 1. The EDX micrographs revealed the morphology of $\mathrm{Bi}_{2} \mathrm{O}_{3}$ is a rod form.

\section{Bismuth-oxygen bonding}

Further result analysis was performed to determine the consistency of synthesized $\mathrm{Bi}_{2} \mathrm{O}_{3}-\mathrm{NR}$. Figure 4 showed the FTIR spectra with absorption band at $845 \mathrm{~cm}^{-1}$. The absorption band at $845 \mathrm{~cm}^{-1}$ is 


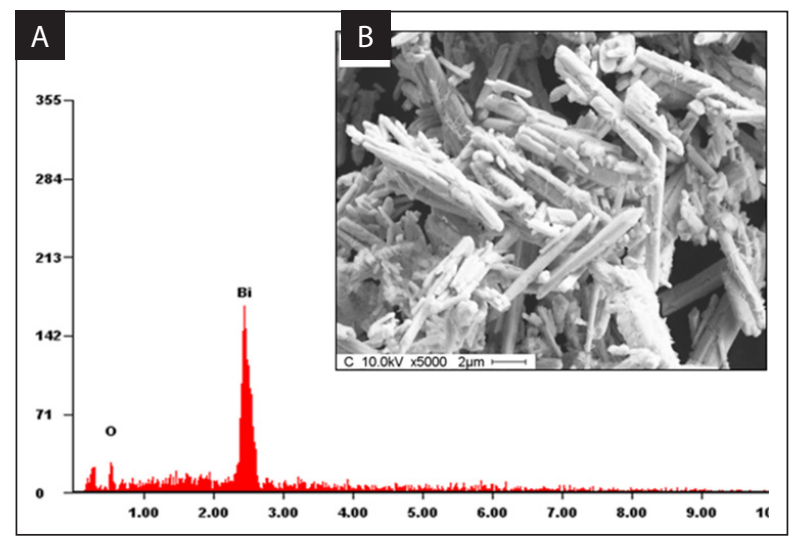

Figure 3. EDX spectrum of $\mathrm{Bi}_{2} \mathrm{O}_{3}-\mathrm{NR}$ synthesized at (A) 10 minutes reaction time and $(\mathbf{B})$ image captured from random spot area

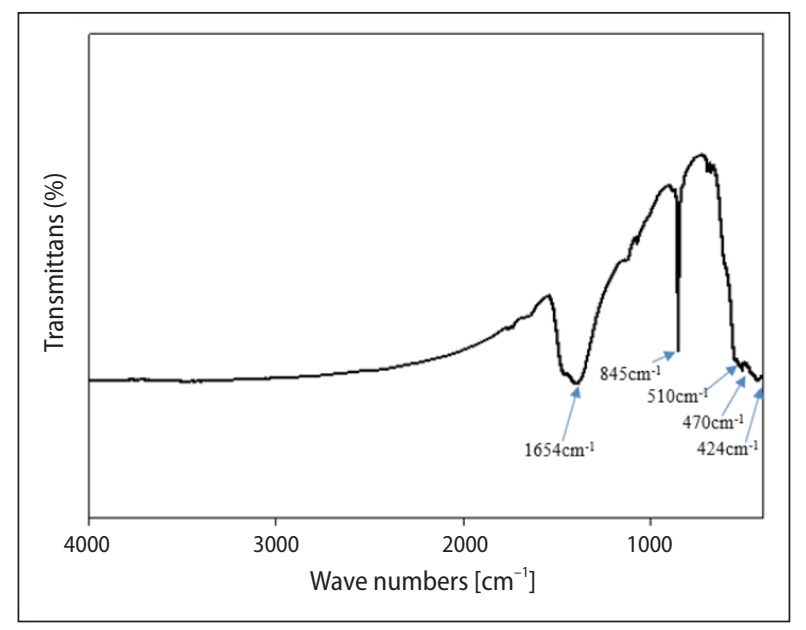

Figure 4. FTIR spectra of $\mathrm{Bi}_{2} \mathrm{O}_{3}-\mathrm{NR}$

a consequence of $\mathrm{Bi}-\mathrm{O}-\mathrm{Bi}$ bonds. The FTIR spectra also show that the absorption band at $424 \mathrm{~cm}^{-1}$ was ascribed to the stretching mode of $\mathrm{Bi}-\mathrm{O}$. Similar data were also reported by Carrazán and team [43]. Three distinct spectra bands at $424 \mathrm{~cm}^{-1}, 470 \mathrm{~cm}^{-1}$ and 510 $\mathrm{cm}^{-1}$ were also recorded, which indicated that the synthesized nanorods were attributed to the monoclinic $\mathrm{Bi}_{2} \mathrm{O}_{3}$. Moreover, the result of the study by Irmawati et al. (2004) which used $\mathrm{Bi}_{2} \mathrm{O}_{3}$ nanocrystals prepared using the precipitation method, showed that EDX spectra bands of all samples display pure monoclinic $\mathrm{Bi}_{2} \mathrm{O}_{3}$ that are similar to our result [44].

\section{The effect of $\mathrm{Bi}_{2} \mathrm{O}_{3}-\mathrm{NR}$ sizes on SER}

The small size of $\mathrm{Bi}_{2} \mathrm{O}_{3}$-NR influences the enhancement of radiosensitization effects based on the results obtained. From Figure 5, the result reveals that the SER value was higher for $\mathrm{Bi}_{2} \mathrm{O}_{3}-\mathrm{NR}$

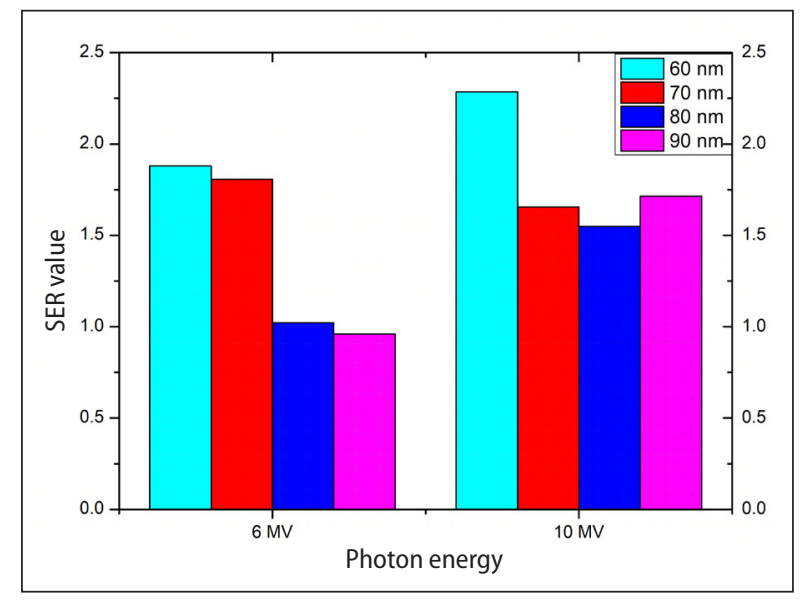

Figure 5. The effect of $60,70,80$ and $90 \mathrm{~nm} \mathrm{Bi} \mathrm{O}_{3}-\mathrm{NR}$ on MCF-7 cell using 6 and $10 \mathrm{MV}$ photon beam

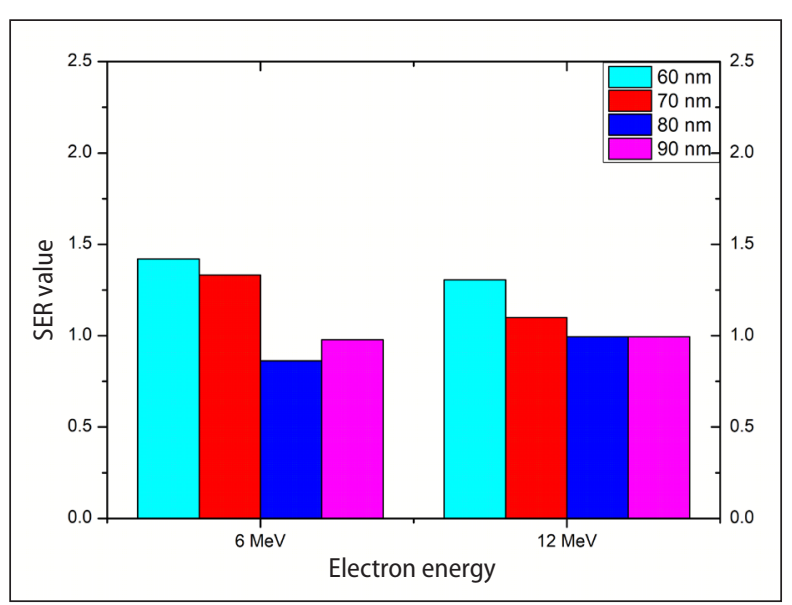

Figure 6. The effect of $60,70,80$ and $90 \mathrm{~nm} \mathrm{Bi}_{2} \mathrm{O}_{3}-\mathrm{NR}$ on MCF-7 cell using 6 and $12 \mathrm{MeV}$ electron beam

of $60 \mathrm{~nm}$ size upon radiation of $6 \mathrm{MV}$ photon beam. Furthermore, upon irradiation with 10 $\mathrm{MV}$ photon beam, $60 \mathrm{~nm}$ size $\mathrm{Bi}_{2} \mathrm{O}_{3}$-NR yielded the highest SER value. The radiosensitization effect using the electron beam, as shown in Figure 6 , showed that the size of $\mathrm{Bi}_{2} \mathrm{O}_{3}$-NR was an essential factor in enhancing the radiotherapy effect. It was found that $60 \mathrm{~nm} \mathrm{Bi}_{2} \mathrm{O}_{3}$-NR yielded the highest SER value for both 6 and $12 \mathrm{MeV}$ electron beams.

Meanwhile, for $70 \mathrm{~nm}$, the SER value was the second-highest followed by 80 and $90 \mathrm{~nm}$ in size. Results produced from this study showed that 60 $\mathrm{nm}$ size $\mathrm{Bi}_{2} \mathrm{O}_{3}$-NR resulted in the most optimum enhancement of radiosensitization, followed by 70 $\mathrm{nm}$. Meanwhile, 80 and $90 \mathrm{~nm}$ sizes were not effective in radiosensitization. 
Particle sizes play an essential role in influencing the ability of nanoparticles to penetrate the layer of the cell membrane. Studies showed that particles larger than $300 \mathrm{~nm}$ have a higher probability of being eliminated by macrophages, while nanoparticles smaller than $100 \mathrm{~nm}$ are less challenging to enter cells. The optimal size of nanoparticles to be absorbed into cells is $50 \mathrm{~nm}$, while smaller nanoparticles of $30 \mathrm{~nm}$ in size will leave the cell via passive diffusion. Comparatively, this study clarified that 60 $\mathrm{nm} \mathrm{Bi}_{2} \mathrm{O}_{3}-\mathrm{NR}$ has a higher potential to be absorbed into the cells as a radiosensitizer. This finding was supported by a previous report that showed that the radiosensitization effect is dependent on smaller size nanoparticles [45]. The research was further supported by in vivo studies in which mice having subcutaneous EMT-6 mammary cancer experienced a higher survival rate $(86 \%)$ when treated with small gold nanoparticles as compared to X-ray alone [46].

The role of particle size in enhancing radiotherapy is still debatable because it was reported that particles of a smaller size than $10 \mathrm{~nm}$ had been shown to be toxic to cells as they tended to be localized within organelles such as mitochondria. Furthermore, nanoparticles of diameter less than $5 \mathrm{~nm}$ could freely diffuse into the nucleus and interact directly with DNA [47]. In the context of interaction, smaller sizes reduce the ability to absorb radiation, hence, reducing the production of the secondary electron. As reported by Brun, Sanche, and Sicard-Roselli, 2009, it was discovered that the optimum enhancement effect occurred when a larger size was used, which gave a 6-fold improvement compared to the control [48]. Chithrani et al., 2010, in their study used nanoparticles sized between 14 and $74 \mathrm{~nm}$, and they found that size plays an essential role in the enhancement of dose to the cancer cell. For $50 \mathrm{~nm}$ size, gold nanoparticles yielded more radiosensitivity because bigger size has a higher content of gold atoms, which, in turn, increases the radiation interaction cross-section and production of a secondary electron [49]. Therefore, to get an optimal radiation effect, every nanoparticle should be evaluated for its ability to penetrate the cell membrane and localize within organelles, both of which are important in maximizing the effect of cell killing.

Besides, the morphology of nanoparticles also affects the enhancement of radiation effects.
A study that used Monte Carlo simulation showed that different morphology of bismuth nanoparticles displayed different enhancement in radiotherapy dose [50]. This study showed that $\mathrm{Bi}_{2} \mathrm{O}_{3}$ nanoparticles could increase the radiosensitivity of cell cancer glioblastoma (9L) with the SER value of 1.48 and 1.25 for the energy of $125 \mathrm{kV}$ and $10 \mathrm{MV}$, respectively. A simulation study using Monte Carlo showed that the platelet morphology per unit of $\mathrm{Bi}_{2} \mathrm{O}_{3}$ mass is the most effective for enhancing the dose, compared to the cubic and spherical morphologies. Comparatively, in this study, $\mathrm{Bi}_{2} \mathrm{O}_{3}-\mathrm{NR}$ also resulted in high SER values of 1.42 and 2.29 when MCF-7 was exposed to $6 \mathrm{MeV}$ electron and $10 \mathrm{MV}$ photon beam energy, respectively. An increase in the radiation dose can also be attributed to the surface area to volume ratio (SA/V). With high SA/V, the ability of metal nanoparticles to absorb high radiation dose is higher, which, in turn, generates many electron pairs due to the contribution from Compton scattering. However, generation of pair production is not the leading cause of cell death because radiosensitization that occurs at this megavoltage energy is caused by the interaction of metal nanoparticles with secondary species produced by ionization of a water medium rather than with the radiation itself [51]. Secondary species are often associated with the production of ROS, which triggers apoptosis and thus contributes to the enhanced radiosensitization.

\section{The effect of $\mathrm{Bi}_{2} \mathrm{O}_{3}-\mathrm{NR}$ on different cell types}

MCF-7 and HeLa cell lines have been used to compare the cell radiosensitivity towards $\mathrm{Bi}_{2} \mathrm{O}_{3}-\mathrm{NR}$ and megavoltage external beam radiotherapy. Both cells were tested with $0.5 \mathrm{uMol} / \mathrm{L}$ of $\mathrm{Bi}_{2} \mathrm{O}_{3}-\mathrm{NR}$ and irradiated with a megavoltage photon and electron beam. Figures 7 and 8 demonstrated that the survival of MCF-7 cells was lower than the HeLa cell. At $6 \mathrm{MV}$ photon beam, SER produced by MCF-7 was 1.88 while HeLa cells were 1.02 only. Meanwhile, at $10 \mathrm{MV}$ energy, the value was 2.29 , which is higher than the HeLa cell (1.07).

The cell survival curve also showed the difference in radiosensitivity in Figures 9 and 10. Upon irradiation with the electron beam at $6 \mathrm{MeV}$, the SER value of MCF-7 was 1.42 while HeLa was 1.39. At $12 \mathrm{MeV}$ energy, $\mathrm{Bi}_{2} \mathrm{O}_{3}$-NR increased the radiotherapy effect up to 1.31 , which means enhance- 


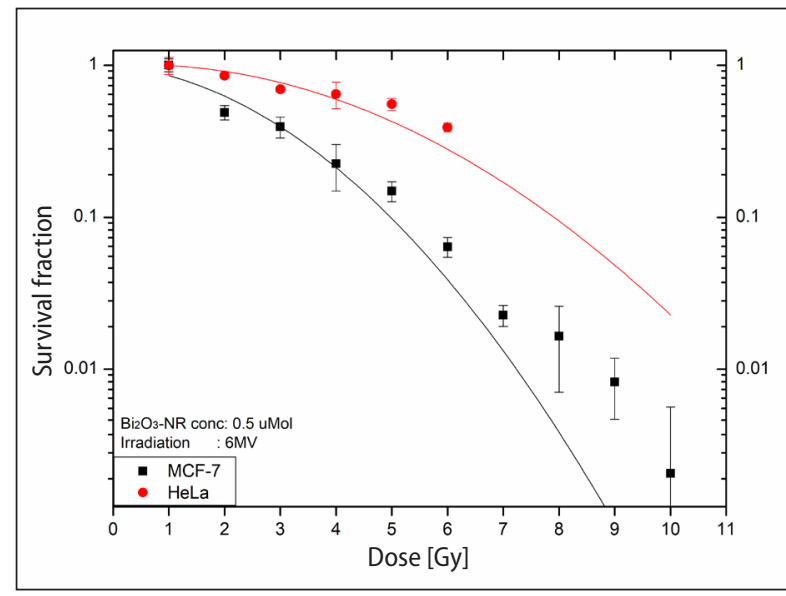

Figure 7. The cell survival curves of MCF-7 and HeLa cell line treated with and without $\mathrm{Bi}_{2} \mathrm{O}_{3}-\mathrm{NR}$ irradiated using $6 \mathrm{MV}$ photon beam

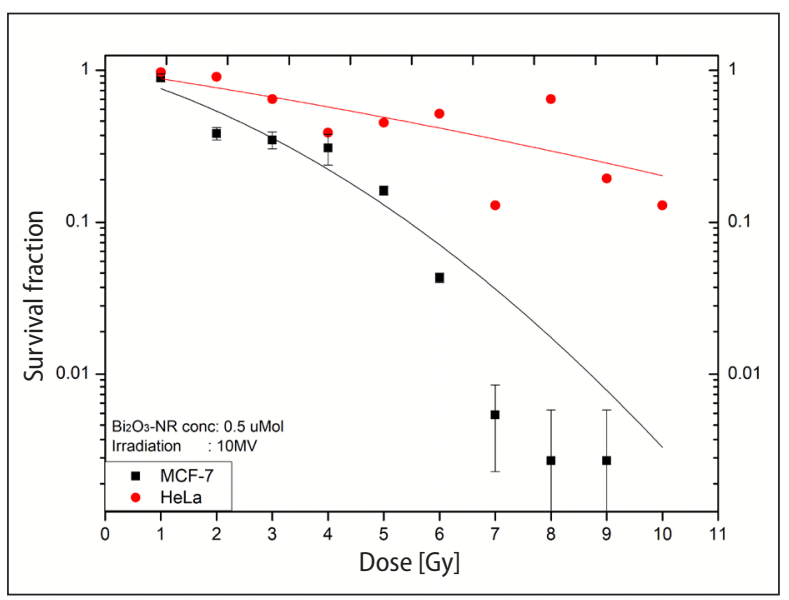

Figure 8. The cell survival curves of MCF-7 and HeLa cell line treated with and without $\mathrm{Bi}_{2} \mathrm{O}_{3}-\mathrm{NR}$ irradiated using $10 \mathrm{MV}$ photon beam

Table 2. SER comparison of MCF-7 and HeLa cell line for $\mathrm{Bi}_{2} \mathrm{O}_{3}-\mathrm{NR}$ size $60 \mathrm{~nm}$. The result show MCF-7 is more radiosensitive than HeLa, mainly when irradiated with a $10 \mathrm{MV}$ photon beam.

\begin{tabular}{|l|c|c|c|c|}
\cline { 2 - 5 } & \multicolumn{3}{c}{ Photon beam } & $6 \mathrm{MeV}$ \\
\cline { 2 - 5 } & $6 \mathrm{MV}$ & $10 \mathrm{MV}$ & 1.42 & 1.31 \\
\hline MCF-7 & 1.88 & 2.29 & 1.39 & 0.74 \\
\hline
\end{tabular}

ment of about $31 \%$ of radiosensitization to MCF-7 cell. Meanwhile, the radiosensitization effect of $\mathrm{Bi}_{2} \mathrm{O}_{3}$-NR was not apparent when HeLa was irradiated at $12 \mathrm{MeV}$. Comparison of SER between both cells was summarized in Table 2 .

Cell survival curves from Figure 7 to 10 showed that MCF-7 cells experienced more death compared to HeLa cells when irradiated with photon and electron beam. These results indicated that the $\mathrm{Bi}_{2} \mathrm{O}_{3}-\mathrm{NR}$ influenced radiosensitization more in MCF-7 cells. Khoshgard (2017) reported that dextran-coated iron oxide nanoparticles increase the effect of radiosensitivity when irradiated with a $6 \mathrm{MV}$ photon beam. It was discovered from the study that MCF-7 cells produced higher SER values $(1.21 \pm 0.06)$ compared to HeLa cells $(1.19 \pm 0.04)$ [52]. The difference is presumably due to the different characteristics of the cells such as type of receptors, number of mitochondria, chromatin structure, all of which affect radiation sensitivity.

Mitochondria play a role in regulating the oxidative stress level inside cells. A study conducted by Anookumar-Dukie and team (2009) showed HeLa cells have a higher resistance to radiation by se- creting MPT blocker cyclosporin A. MPT blocker cyclosporin A functions to attenuate irradiation-induced ROS production, thereby, protecting the cells from radiation that can damage DNA and other organelles [53].

Based on Table 2, the highest SER is marked at 6 $\mathrm{MV}$ and $10 \mathrm{MV}$ energy photon beam compared to the electron beam using the MCF-7 cell line. This event is explained in previous studies that MV photons exhibit an excellent radiosensitization using nanoparticles with a high- $Z$ number [54-57]. This event is due to electron impact and photoionization occurrence in the collimated area of dose-build up, hence, radiosensitization by $\mathrm{Bi}_{2} \mathrm{O}_{3}-\mathrm{NR}$ in $6 \mathrm{MV}$ and $10 \mathrm{MV}$ photon beam is higher because the multiple interaction occurrence, which decrease the primary radiation before interaction with the samples, thus, increasing radiation absorption. The Compton scattering within the water-phantomand bolus-sandwiched samples might also indirectly produce higher radiosensitization by $\mathrm{Bi}_{2} \mathrm{O}_{3}-\mathrm{NR}$ by decreasing the mean photon energy surrounding $\mathrm{Bi}_{2} \mathrm{O}_{3}-\mathrm{NR}$, recovering photoelectric interaction probability, which increases the Auger cascades. 


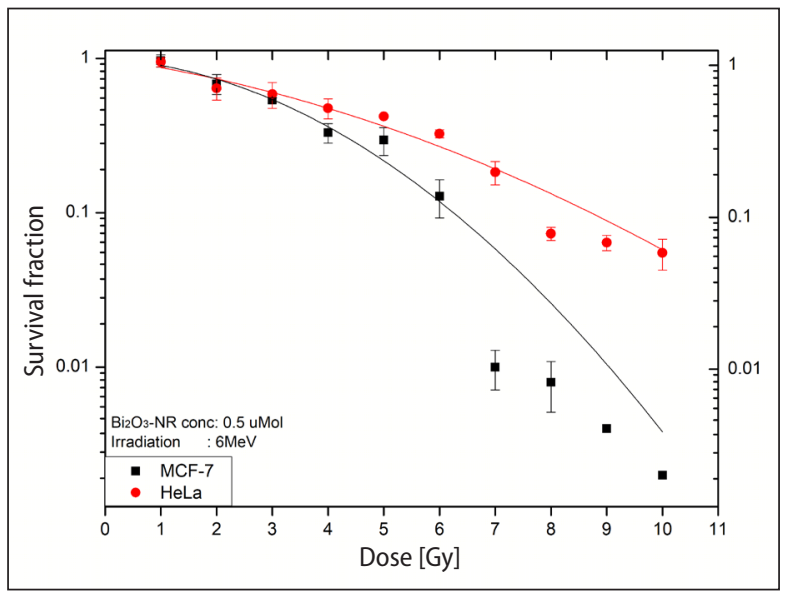

Figure 9. The cell survival curves of MCF-7 and HeLa cell line treated with and without $\mathrm{Bi}_{2} \mathrm{O}_{3}-\mathrm{NR}$ irradiated using $6 \mathrm{MeV}$ electron beam

High SER in photon beam compared to electron beam radiotherapy and brachytherapy when using high $-\mathrm{Z}$ nanoparticles is also mentioned in another study by Talik Sisin et al., 2020 [58].

\section{Conclusion}

In this study, $\mathrm{Bi}_{2} \mathrm{O}_{3}$-NR of $60 \mathrm{~nm}$ size generated the highest SER, which indicates the potential to reduce cancer cells survival. Data generated from this study suggest that the use of smaller size $\mathrm{Bi}_{2} \mathrm{O}_{3}$-NR is the main factor that determines the effectiveness of radiotherapy. This study also discovered that MCF-7 had higher radiosensitivity compared to $\mathrm{HeLa}$ when $\mathrm{Bi}_{2} \mathrm{O}_{3}$-NR was used and proved that different cell types exhibit different levels of radiosensitivity. Lastly, the SER in photon beam radiotherapy marked the highest compared to electron beam radiotherapy energy due to increased interaction within the samples, resulting in decreased primary radiation energy and higher Compton scattering.

\section{Conflict of interest}

The authors declare no conflict of interest.

\section{Funding and acknowledgement}

This research is financially supported by the Fundamental Research Grant Scheme (203. PPSK.6171256), and we want to thank Advanced Medical and Dental Institute, Universiti Sains Malaysia for their kind gesture in providing their facilities for us to use in this research.

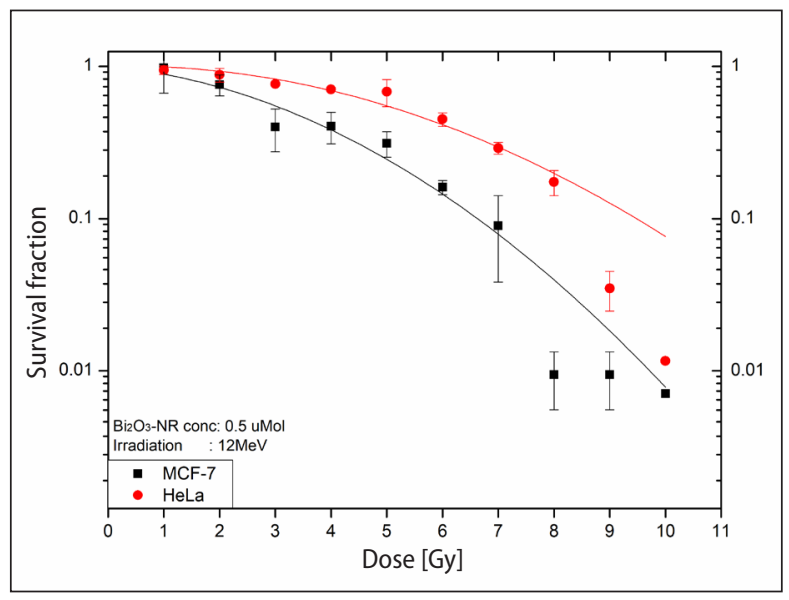

Figure 10. The cell survival curves of MCF-7 and HeLa cell line treated with and without $\mathrm{Bi}_{2} \mathrm{O}_{3}-\mathrm{NR}$ irradiated using $12 \mathrm{MeV}$ electron beam

\section{References}

1. Boateng F, Ngwa W. Delivery of Nanoparticle-Based Radiosensitizers for Radiotherapy Applications. Int J Mol Sci. 2019; 21(1), doi: 10.3390/ijms21010273, indexed in Pubmed: 31906108.

2. Ngwa W, Kumar R, Moreau M, et al. Nanoparticle Drones to Target Lung Cancer with Radiosensitizers and Cannabinoids. Front Oncol. 2017; 7: 208, doi: 10.3389/ fonc.2017.00208, indexed in Pubmed: 28971063.

3. Boateng F. In Silico Study of Smart Radiotherapy Biomaterials for Radiotherapy Alications. Vol. 10675302. ProQuest Dissertations Publishing, Lowell 2017: 1-118.

4. Pottier A, Borghi E, Levy L. The future of nanosized radiation enhancers. Br J Radiol. 2015; 88(1054): 20150171, doi: 10.1259/bjr.20150171, indexed in Pubmed: 26248871.

5. Kwatra D, Venugopal A, Anant S. Nanoparticles in radiation therapy: A summary of various approaches to enhance radiosensitization in cancer. Transl Cancer Res. 2013; 2(4): 330-342, doi: 10.3978/j.issn.2218-676X.2013.08.06.

6. Zhang P, Qiao Y, Xia J, et al. Enhanced radiation therapy with multilayer microdisks containing radiosensitizing gold nanoparticles. ACS Appl Mater Interfaces. 2015; 7(8): 4518-4524, doi: 10.1021/am506866a, indexed in Pubmed: 25679345.

7. Paro AD, Shanmugam I, van de Ven AL. Nanoparticle-Mediated X-Ray Radiation Enhancement for Cancer Therapy. Methods Mol Biol. 2017; 1530:391-401, doi: 10.1007/9781-4939-6646-2_25, indexed in Pubmed: 28150217.

8. Atun R, Jaffray DA, Barton MB, et al. Expanding global access to radiotherapy. Lancet Oncol. 2015; 16(10): 11531186, doi: 10.1016/S1470-2045(15)00222-3, indexed in Pubmed: 26419354.

9. Kvols LK. Radiation sensitizers: a selective review of molecules targeting DNA and non-DNA targets. J Nucl Med. 2005; 46 Suppl 1: 187S-90S, indexed in Pubmed: 15653668.

10. Tang Le, Wei F, Wu Y, et al. Role of metabolism in cancer cell radioresistance and radiosensitization methods. J Exp Clin Cancer Res. 2018; 37(1): 87, doi: 10.1186/s13046-0180758-7, indexed in Pubmed: 29688867. 
11. Kwatra D, Venugopal A, Anant S. Nanoparticles in radiation therapy: A summary of various approaches to enhance radiosensitization in cancer. Transl Cancer Res. 2013; 2(4): 330-342, doi: 10.3978/j.issn.2218-676X.2013.08.06.

12. Zhang P, Qiao Y, Xia J, et al. Enhanced radiation therapy with multilayer microdisks containing radiosensitizing gold nanoparticles. ACS Appl Mater Interfaces. 2015; 7(8): 4518-4524, doi: 10.1021/am506866a, indexed in Pubmed: 25679345.

13. Paro AD, Shanmugam I, van de Ven AL. Nanoparticle-Mediated X-Ray Radiation Enhancement for Cancer Therapy. Methods Mol Biol. 2017; 1530: 391-401, doi: 10.1007/9781-4939-6646-2_25, indexed in Pubmed: 28150217.

14. Nagi NMS, KhairYAM, Abdalla AME. Capacity of gold nanoparticles in cancer radiotherapy. Jpn J Radiol. 2017;35(10): 555-561, doi: 10.1007/s11604-017-0671-6, indexed in Pubmed: 28795273.

15. Cheng YJ, Nie XY, Ji CC, et al. Long-Term Cardiovascular Risk After Radiotherapy in Women With Breast Cancer. J Am Heart Assoc. 2017; 6(5), doi: 10.1161/JAHA.117.005633, indexed in Pubmed: 28529208.

16. Nimmagadda S, Ford EC, Wong JW, et al. Targeted molecular imaging in oncology: focus on radiation therapy. Semin Radiat Oncol. 2008; 18(2): 136-148, doi: 10.1016/j. semradonc.2007.10.009, indexed in Pubmed: 18314068.

17. Willers H, Azzoli CG, Santivasi WL, et al. Basic mechanisms of therapeutic resistance to radiation and chemotherapy in lung cancer. Cancer J. 2013; 19(3): 200-207, doi: 10.1097/PPO.0b013e318292e4e3, indexed in Pubmed: 23708066.

18. Boateng F, Ngwa W. Modeling gold nanoparticle-eluting spacer degradation during brachytherapy application with in situ dose painting. Br J Radiol. 2017; 90(1074): 20170069, doi: 10.1259/bjr.20170069, indexed in Pubmed: 28383280.

19. Farokhzad OC, Langer R. Impact of nanotechnology on drug delivery. ACS Nano. 2009; 3(1): 16-20, doi: 10.1021/ nn900002m, indexed in Pubmed: 19206243.

20. Wang $\mathrm{H}, \mathrm{Mu} \mathrm{X}, \mathrm{He} \mathrm{H}$, et al. Cancer Radiosensitizers. Trends Pharmacol Sci. 2018; 39(1): 24-48, doi: 10.1016/j. tips.2017.11.003, indexed in Pubmed: 29224916.

21. Rashid RA, Abidin SZ, Anuar MK, et al. Radiosensitization effects and ROS generation by high Z metallic nanoparticles on human colon carcinoma cell (HCT116) irradiated under $150 \mathrm{MeV}$ proton beam. OpenNano. 2019; 4: 100027, doi: 10.1016/j.onano.2018.100027.

22. Rashid R, Razak K, Geso M, et al. Radiobiological Characterization of the Radiosensitization Effects by Gold Nanoparticles for Megavoltage Clinical Radiotherapy Beams. BioNanoScience. 2018; 8(3): 713-722, doi: 10.1007/ s12668-018-0524-5.

23. K.A. M, Rashid R, Lazim R, et al. Evaluation of radiosensitization effects by platinum nanodendrites for $6 \mathrm{MV}$ photon beam radiotherapy. Radiation Physics and Chemistry. 2018; 150: 40-45, doi: 10.1016/j.radphyschem.2018.04.018.

24. Rahman WN. Gold nanoparticles: novel radiobiological dose enhancement studies for radiation therapy, synchrotron based microbeam and stereotactic radiotherapy. RMIT University, Melbourne 2010.

25. Xiong Y, Wu M, Ye J, et al. Synthesis and luminescence properties of hand-like a-Bi2O3 microcrystals. Materials
Letters. 2008; 62(8-9): 1165-1168, doi: 10.1016/j.matlet.2007.08.004.

26. Yang Q, LiY, Yin Q, et al. Bi4Ti3O12 nanoparticles prepared by hydrothermal synthesis. J Eur Ceram Soc. 2003; 23(1): 161-166, doi: 10.1016/s0955-2219(02)00087-0.

27. Jeon S, Park S, Yu J, et al. Selective Synthesis of Nanospheres and Nanosheets of Bismuth Subcarbonate. Chemistry Lett. 2015; 44(12): 1717-1719, doi: 10.1246/cl.150867.

28. Yang H, Yan Y, Li J, et al. Low-temperature Hydrothermal Synthesis of Bismuth Nanoflowers and Their Application for Heavy Metal Detection. Chemistry Lett. 2013; 42(2): 150-152, doi: 10.1246/cl.2013.150.

29. Helal A, Harraz F, Ismail A, et al. Controlled synthesis of bismuth sulfide nanorods by hydrothermal method and their photocatalytic activity. Materials \& Design. 2016; 102: 202-212, doi: 10.1016/j.matdes.2016.04.043.

30. $\mathrm{KIM} \mathrm{H,} \mathrm{LEE} \mathrm{J,} \mathrm{SHIM} \mathrm{S.} \mathrm{Study} \mathrm{of} \mathrm{Bi2O3} \mathrm{nanorods} \mathrm{grown} \mathrm{using}$ the MOCVD technique. Sensors and Actuators B: Chemical. 2007; 126(1): 306-310, doi: 10.1016/j.snb.2007.01.002.

31. Li L, Yang YW, Li GH, et al. Conversion of a Bi nanowire array to an array of $\mathrm{Bi}-\mathrm{Bi} 2 \mathrm{O} 3$ core-shell nanowires and Bi2O3 nanotubes. Small. 2006; 2(4): 548-553, doi: 10.1002/ smll.200500382, indexed in Pubmed: 17193084.

32. Li J, Liu X, Cui J, et al. Hydrothermal synthesis of selfassembled hierarchical tungsten oxides hollow spheres and their gas sensing properties. ACS Appl Mater Interfaces. 2015; 7(19): 10108-10114, doi: 10.1021/am508121p, indexed in Pubmed: 25919799.

33. Xu G, Ren Z, Du P, et al. Polymer-Assisted Hydrothermal Synthesis of Single-Crystalline Tetragonal Perovskite PbZr0.52Ti0.4803 Nanowires. Advanced Materials. 2005; 17(7): 907-910, doi: 10.1002/adma.200400998.

34. Byrappa K, Adschiri T. Hydrothermal technology for nanotechnology. Prog Crystal Growth Charact Mat. 2007; 53(2): 117-166, doi: 10.1016/j.pcrysgrow.2007.04.001.

35. Muruganandham M, Amutha R, Lee GJ, et al. Facile Fabrication of Tunable Bi2O3 Self-Assembly and Its Visible Light Photocatalytic Activity. J Phys Chem C. 2012; 116(23): 12906-12915, doi: 10.1021/jp302343f.

36. Wu C, Shen Li, Huang Q, et al. Hydrothermal synthesis and characterization of $\mathrm{Bi} 2 \mathrm{O} 3$ nanowires. Materials Lett. 2011;65(7): 1134-1136, doi: 10.1016/j.matlet.2011.01.021.

37. Yang Q, Li Y, Yin Q, et al. Hydrothermal synthesis of bismuth oxide needles. Materials Lett. 2002; 55(1-2): 46-49, doi: 10.1016/s0167-577x(01)00617-6.

38. Chen W, Zhang J. Using nanoparticles to enable simultaneous radiation and photodynamic therapies for cancer treatment. J Nanosci Nanotechnol. 2006; 6(4): 1159-1166, doi: 10.1166/jnn.2006.327, indexed in Pubmed: 16736782.

39. Bharti DB, Bharati AV. Synthesis of ZnO nanoparticles using a hydrothermal method and a study its optical activity. Luminescence. 2017; 32(3): 317-320, doi: 10.1002/ bio.3180, indexed in Pubmed: 27430489.

40. Aneesh PM, Vanaja KA, Jayaraj MK. Synthesis of ZnO nanoparticles by hydrothermal method. Nanophotonic Materials IV. 2007, doi: 10.1117/12.730364.

41. Pan Yu, Neuss S, Leifert A, et al. Size-dependent cytotoxicity of gold nanoparticles. Small. 2007; 3(11): 1941-1949, doi: 10.1002/smll.200700378, indexed in Pubmed: 17963284.

42. Huang K, Ma H, Liu J, et al. Size-dependent localization and penetration of ultrasmall gold nanoparticles in cancer cells, multicellular spheroids, and tumors in vivo. ACS 
Nano. 2012; 6(5): 4483-4493, doi: 10.1021/nn301282m, indexed in Pubmed: 22540892.

43. Ngwa W, Makrigiorgos GM, Berbeco RI. Applying gold nanoparticles as tumor-vascular disrupting agents during brachytherapy: estimation of endothelial dose enhancement. Phys Med Biol. 2010; 55(21): 65336548, doi: 10.1088/0031-9155/55/21/013, indexed in Pubmed: 20959684.

44. Irmawati R, Nasriah MNN, Taufiq-Yap YH, et al. Characterization of bismuth oxide catalysts prepared from bismuth trinitrate pentahydrate: influence of bismuth concentration. Catalysis Today. 2004; 93-95: 701-709, doi: 10.1016/j. cattod.2004.06.065.

45. Lechtman E, Pignol JP. Interplay between the gold nanoparticle sub-cellular localization, size, and the photon energy for radiosensitization. Sci Rep. 2017; 7(1): 13268, doi: 10.1038/s41598-017-13736-y, indexed in Pubmed: 29038517.

46. Hainfeld JF, Slatkin DN, Smilowitz HM. The use of gold nanoparticles to enhance radiotherapy in mice. Phys Med Biol. 2004; 49(18): N309-N315, doi: 10.1088/00319155/49/18/n03, indexed in Pubmed: 15509078.

47. Pan Yu, Neuss S, Leifert A, et al. Size-dependent cytotoxicity of gold nanoparticles. Small. 2007; 3(11): 1941-1949, doi: 10.1002/smll.200700378, indexed in Pubmed: 17963284.

48. Brun E, Sanche L, Sicard-Roselli C. Parameters governing gold nanoparticle $\mathrm{X}$-ray radiosensitization of DNA in solution. Colloids Surf B Biointerfaces. 2009; 72(1): 128-134, doi: 10.1016/j.colsurfb.2009.03.025, indexed in Pubmed: 19414242.

49. Chithrani DB, Jelveh S, Jalali F, et al. Gold nanoparticles as radiation sensitizers in cancer therapy. Radiat Res. 2010; 173(6): 719-728, doi: 10.1667/RR1984.1, indexed in Pubmed: 20518651.

50. Stewart CA. An Investigation into the Tailoring of Bismuth Oxide Nanoceramic with a Biomedical Application as a High Z Radiation Enhancer for Cancer Therapy. University of Wollongong, Wollongong 2014.
51. McMahon SJ, Paganetti H, Prise KM. Optimising element choice for nanoparticle radiosensitisers. Nanoscale. 2016; 8(1): 581-589, doi: 10.1039/c5nr07089a, indexed in Pubmed: 26645621.

52. Khoshgard K, Kiani P, Haghparast A, et al. Radiation dose rate affects the radiosensitization of MCF- 7 and HeLa cell lines to $X$-rays induced by dextran-coated iron oxide nanoparticles. Int J Radiat Biol. 2017; 93(8): 757-763, doi: 10.108 0/09553002.2017.1321806, indexed in Pubmed: 28452253.

53. Anoopkumar-Dukie S, Conere T, Sisk GD, et al. Mitochondrial modulation of oxygen-dependent radiosensitivity in some human tumour cell lines. Br J Radiol. 2009; 82(982): 847-854, doi: $10.1259 / \mathrm{bjr} / 35746067$, indexed in Pubmed: 19366737.

54. Ngwa W, Makrigiorgos GM, Berbeco Rl. Gold nanoparticle-aided brachytherapy with vascular dose painting: estimation of dose enhancement to the tumor endothelial cell nucleus. Med Phys. 2012; 39(1): 392-398, doi: 10.1118/1.3671905, indexed in Pubmed: 22225308.

55. Morozov KV, Kolyvanova MA, Kartseva ME, et al. Radiosensitization by Gold Nanoparticles: Impact of the Size, Dose Rate, and Photon Energy. Nanomaterials (Basel). 2020; 10(5), doi: 10.3390/nano10050952, indexed in Pubmed: 32429500.

56. Jeremic B, Aguerri AR, Filipovic N. Radiosensitization by gold nanoparticles. Clin Transl Oncol. 2013; 15(8): 593-601, doi: 10.1007/s12094-013-1003-7, indexed in Pubmed: 23359187.

57. Feynman RP, Vernon FL. The theory of a general quantum system interacting with a linear dissipative system. Ann Phys. 1963; 24: 118-173, doi: 10.1016/00034916(63)90068-x.

58. Talik Sisin NN, Abdul Razak K, Zainal Abidin S, et al. Synergetic Influence of Bismuth Oxide Nanoparticles, Cisplatin and Baicalein-Rich Fraction on Reactive Oxygen Species Generation and Radiosensitization Effects for Clinical Radiotherapy Beams. Int J Nanomedicine. 2020; 15: 7805-7823, doi: $10.2147 /$ IJN.S269214, indexed in Pubmed: 33116502. 